\title{
7 \\ Aspects of the Narrator
}

Probably no strategy in academic criticism of the novel has proved more powerful in our own time than the separation of the narrator from the narration. Nevertheless, although the sophistication of this separation remained a task for a literary selfconsciousness that had not yet developed by the mid-nineteenth century, reviewers did approach the novel as an expression of authorial voice as well as the recital of a story. It was obvious to them that every novel was written in words, had a style, and implied a teller. As with all other novelistic elements, they assessed this expression in terms of its enhancement, or lack thereof, of the reading experience. What was wanted above all was a style that was lively, a tone that was (as the word implies) tonic, and a narrator who was agreeable so that reading would be fun. Thus, at just the point where some contemporary critics anticipate and applaud differences between novelists as well as between individual novels. by a single author, reviewers of this earlier time looked for uniformity.

But then again, since reviewers entered the novel at a high level of its organization and did not reduce it to those transpersonal linguistic elements that the novel would share with all other forms of written language, their commentary on the narrator tended to be impressionistic, subjective, and sensitive to individual differences. Although they may not have intended this, their discussion had the interesting effect of leaving the "magic" of the novel unimpaired; since they did not dissect, they did not murder. Entirely missing from their conceptual universe was the notion that the world language referred to was, in even the 
slightest degree, a linguistic creation; but in a curious sense this structuralist and poststructuralist notion would be irrelevant to their criticism, since the level at which language might create the world was far below the level at which they were operating. They did not interpret novels, nor did they look to novels as a source for speculation (their own or the novelists') on interpretation itself.

Even the briefest review usually commented on style. The commentary was concerned to describe the effect of style rather than its production, and the vocabulary was narrow. All styles were assessed in terms of an idea of good style, an idea with two basic constituents: first, that the language conformed to accepted usage, both syntactical and lexical; second, that the style was animated. Although they never articulated the point, reviewers' comments took style to be the vital principle of the novel in the sense of making its story live for the reader. Distinctiveness of style might be noted or described, but it did not form the basis for judgment unless the style was especially idiosyncratic. When it was, reviewers were more inclined to be critical than commendatory. Thus, for example, though musical cadence and harmony in style were desirable as enhancement of reading pleasure as well as emphasis of the forward movement of the prose, a reviewer would regularly object to a style that was "painfully ornate, ambitious ... full of musical circumlocution introduced evidently for the sake of the music" (Southern Literary Messenger, June 1847 , reviewing Bulwer). In contrast, the Literary World (November I7, I 849) approved of Melville's style in Redburn because it had "no verbosity, no artificiality, no languor: the style is always exactly filled by the thought and material."

The comments above should not be interpreted as implying that style should or could be a transparent envelope for what it contained, for if so one could not tell when the matter filled the style and when style was being exhibited for its own sake. Rather, these two remarks imply a sense of style as instrumental, and as beautiful when (and only when) it is functional. The relatively florid norms of Victorian prose style should not obscure the point that functionality was the criterion. The residue of nonfunctional style could only act as impediment or distraction. Since language was ineluctably representational, it could only point to the author when it did not point to the story, and, 
more specifically, to an author pointing to himself. Thus nonfunctional style immediately implied a self-indulgent or exhibitionist author, a disagreeable character who was assumed to interfere with the enjoyment of the novel. In this basic fashion, a nonfunctional style could only be self-defeating. The popularity of egotistical authors like Bulwer did not change this judgment.

The general terms employed to praise a style fall into a few clusters. The most common word of praise was "vigorous," and along with it came such related terms as animated, powerful, terse, bold, nervous, vivid, vivacious, spirited, warm, elastic, impassioned, salient, racy, energetic, original, direct, expressive, sprightly. The second most common operative concept was most of ten expressed by the word "graceful," along with its relatives: melodious, fluent, flowing, harmonious, sweet, cadenced. Together these two constituents-power and grace-formed the life of a style. Ideally a style combined vigor and grace, but if reviewers had to choose between these two qualities they preferred vigor.

To some degree vigor in style was associated with the masculine, grace with the feminine: "her style ... though frequently showing an almost masculine energy, is destitute of the sweet and graceful fluency which would finely attemper her bold and striking conceptions" (Harper's on Caroline Chesebro', January I 852). Vigor and grace, however, were assessed apart from the author's gender: reviewers expected women and men to write differently but used the same criteria in evaluating their styles. Commenting on style in another of Chesebro's works, Harper's said it "is always sinewy and masculine, often highly picturesque.... We much prefer the robust and well-compacted phraseology of this work, animated as it is by the workings of an original and active mind, to the soft and polished sweetnesses of many of our fashionable sentence-makers" (May I 855).

Cutting across this set of terms is another, represented at one extreme by such descriptive words of praise as elegant, rich, brilliant, fresh, original, varied, picturesque, and at the other by words like chaste, pure, simple, concise, plain, unaffected. Just as power and grace were constituent elements of style that ought to be combined but also might come into conflict, so in the best styles elegance blended with chastity while lesser writers tended to achieve one or the other but not both of these desirable 
qualities. Elegance has to do with complexity and subtlety and implies a wealth of lexical, syntactic, and rhetorical resources; chastity is equated with simplicity and austerity. Where in choosing between vigor and grace reviewers preferred vigor, between elegance and chastity they chose chastity. The reasons for this preference are not entirely clear, but of course (though we no longer use the words chaste and pure) we continue to prefer simplicity and direct statement, as any survey of writers' manuals will show. Today, however, we associate directness and simplicity with the masculine and elegance with the feminine, associations impossible to an era in which simplicity connoted purity and chastity.

The chief stylistic challenge in novel writing was also the novel's chief mystery: a dead style meant a dead novel. For in fact neither elegance nor chastity nor both could guarantee stylistic vigor or power, while the deliberate effort to achieve power was likely to create an unpleasant sense of strain. Style was most frequently criticized for being "ambitious," a condition manif ested through inflation, mannerism, exaggeration, or labored attempts at "fine writing"- through being studied, ponderous, affected, obscure, ornate, luxurious, diffuse. Striving for more, the writer achieved less. There was something here beyond the power of criticism to analyze, something accepted as magic. Hawthorne's many discussions, embedded in his fictions, of the way the writer "animated" his works, refer to this magical vigor. Melville's late works were particularly subject to negative stylistic assessment on these grounds, and in my view it was much more likely his style than his subject or his morality that hurt him with the public in the instances of both Mardi and Pierre.

Inflation or ornateness pointed on the one hand to lack of skill or (even more significantly, perhaps) lack of talent; it pointed on the other to a fatal vanity and pretension in the author, an exhibitionism that implied the author had forgotten his place as conveyor of a story, servant both to his tale and to his readers. This is why the word ambitious was so of ten used to criticize a "fine" style-it betrayed the author's desire to be seen in the work, to be noticed as author. So the North American Review for October I 848 wrote that Grantly Manor is "stirred too often by an ambition for the superfine, to catch that flowing felicity of style which should be the aim of the novelist, - a style in which sentences should 
only represent thought or fact, and never dazzle away attention from the matter they convey." And, conversely, it praised Hawthorne's style in a July I 850 review: "his style may be compared to a sheet of transparent water, reflecting from its surface blue skies, nodding woods, the smallest spray or flower that peeps over its grassy margin, while in its clear yet mysterious depths we espy rarer and stranger things. . . Every thing charms the eye and ear, and nothing looks like art and painstaking. There is a naturalness and a continuous flow of expression in Mr. Hawthorne's books, that makes them delightful to. read." The North American reviewer clearly knows that this natural impression is the result of great art, going on to describe Hawthorne as "master" of a "wizard power over language." By effacing himself in the service of his art, the writer in fact achieves the mastery that he does not attain. when he deliberately displays himself. This is indeed a mystery the reviewer is content to leave mystified, as the vocabulary of magic shows.

The intervention of the colloquial novel between those times and our own—of, let us say, Huckleberry Finn—makes it difficult to appreciate that "fine writing" was the greatest stylistic defect to mid-nineteenth-century reviewers, because their "plain style" was so much more ornate than ours. In addition, it is true, reviewers objected to colloquial narration. For them, slang, colloquialism, and "bad grammar," as well as neologisms and foreign terms, all indicated the same lack of skill that a fine style implied. The writer was either ignorant of the resources of language or of the conventions of the form he or she was using, or was knowingly rejecting them. This last was not perceived as admirable, for all reviewers assumed that the language was more than adequate for any use a novelist might want to put it to. The North American for April I 85 I complained about Judd's Richard Edney in this way: Judd is "a genius, but unhappily, he is no artist. His work is full of errors any schoolboy of regular training would be able to correct." It protested against the book's "motley style," its "practice of introducing vulgar idioms and words coined at will," its "use of provincialisms, and the most homely colloquial diction." These, it granted, are "not without precedent in the best writers of fiction. But they are used as characteristics of the inferior personages, or under an assumed name and character, to which they are natural and appropriate. No respectable writer 
adopts them into his own proper vocabulary, and parades them in defiance of polite usage, whatever may be his theme or purpose."

One can hardly avoid noticing that the norms of polite and respectable society are taken as the norms of fictional style; but it would be wrong to infer from this that the reviewers were taking this style to be "natural," that is, were pretending that these particular cultural norms were in the nature of things or that the style they admired could be achieved without effort and practice. On the contrary, the review makes it quite clear that achieving the convention of the narrator's voice is a test of the author's ability. To drop into a low style is no different, structurally speaking, from rising into labored pomposity: both call attention to the writer as writer. The writer who adopts standard English becomes, by convention, invisible. The writer who uses colloquialisms or vulgar idioms or neologisms calls attention to himself as uneducated, unskilled, presumptuous; the work then becomes an instance of the author and loses its own proper life. (It is ironic that as writers more and more claimed the right to intrude themselves into their work by ignoring or disrupting conventions, hence reminding readers that the work was "only a novel," the novel did become a less magical, less lively form; and then, in one more turn of the screw, as critics uncovered hitherto invisible novelists in conventional works by exposing conventions, the magic life of the work passed from the author to the critic.)

Within the field defined by these four clusters-vigor, grace, elegance, purity-authors might naturally and properly achieve individual variations of style, which could form the basis for a reviewer's description and constitute part of a reader's appreciation. But it was the ineluctable tendency of this approach to praise and encourage normative style, as is still largely the case today where expository writing is concerned, even though fiction is now an allowed site for stylistic idiosyncrasy. In the midnineteenth-century review, it was rare indeed that a highly individual style was praised for its individuality. Of the several hundred authors noticed in the reviews of my sample, only three are regularly singled out in this way: E. D. E. N. Southworth, Charles Reade, and Charles Dickens.

Southworth's is a particularly interesting case, because at first 
her works were condemned for their stylistic excesses. As her popularity became manifest, reviewers perceived her appeal as grounded at least partly in that same style, indeed in the very qualities they had objected to; hence they changed their vocabulary when describing it. Harper's first review of Southworth (October I 852 ) considered The Discarded Daughter: "the author of this novel possesses a singularly vivid imagination, and a rare command of picturesque expression. She evinces originality, depth and fervor of feeling, vigor of thought, and dramatic skill; but so blended with glaring faults, that the severest critic would be her best friend. . . . With the constant effort to surprise, the language becomes inflated, and at the same time is often careless to a degree, which occasions the most ludicrous sense of incongruity. ... Let her tame the genial impetuosity of her pen by a due reverence for classical taste and common sense-and she will yet attain a rank worthy of her fine faculties, from which she has hitherto been precluded by her outrages on the proprieties of fictitious composition." But a later Harper's reviewer modified this approach, finding The Lost Heiress "the most finished production which has come from the pen of this fertile writer" whose faults proceeded "from an exuberant imagination and an excessive facility of language - but its vigor of conception and brilliancy of description make it one of the most readable novels of the season" (January I 855). And in November of that year a review of Southworth's The Deserted Wife referred to "the exuberant splendor of style for which that writer is remarkable." The Southern Literary Messenger observed more laconically that "the admirers of Mrs. Southworth, and she has created many by her passionately sensuous style, will no doubt find The Missing Bride highly entertaining" (July I 855). Southworth's stylistic extravagances matched her outsized characters and brought her improbable plots to life; the whole, being larger than life, provided readers with the sense of power and energy they sought in novels.

The mannered style of Charles Reade occasioned a different sort of critical debate. The Tribune found his language "free from the conventionalities of fictitious writing, and often has a salient freshness which goes far to account for their attractions, without referring to any skill in construction of plot, or the delineation of character" (June 26, I855). A review in the Southern Literary Mes- 
senger observed similarly that "his short crisp sentences have a brilliancy and point which would not fail to make him popular, even if his subjects and the manner in which they are treated were not equally original" (November 1855 ). But another review in the same journal (October I 856) proclaimed that "we cannot sanction the absurd tricks of typography and ridiculous brevity of chapters to which Mr. Reade has resorted to produce effect." The Atlantic, reviewing White Lies, observed that "the early chapters of this novel lack the brisk movement, the sparkling compactness, the stinging surprises of Mr. Reade's usual style, but he kindles and condenses as he proceeds"; it concluded that Reade was "a writer difficult to criticize, because his defects are pleasing defects" (November I 857). The same journal reviewing his Love Me Little, Love Me Long found it "pleasant to see how unreservedly Mr. Reade has abandoned his functions as apostle of grammatical free-love. Of tricks of typography there are also fewer, although these yet remain in an excess which good taste can hardly sanction. We often find whole platoons of admirationpoints stretching out in line, to give extraordinary emphasis to sentences already sufficiently forcible" (July I 859). A review for the North American, too, noted that his "peculiarities of style are strongly marked," that he had "tricks of speech" that "sometimes verge on bad taste," and that his "curt and crispy style, in which he is often very successful, needs but a slight exaggeration to become positively ludicrous as well as weak" (July I 859).

Reviewers faulted both these authors for straining after effect; where strain was noticeable, effect was not achieved. But their commentary implies a gap between them and readers in general; either readers did not object to strain, or their less analytic reading habits led them to overlook it. Since some reviews suggest that elaborate style might be a reason for these novelists' popularity, the possibility exists that readers noted, and enjoyed, an ornamental style: straining after effect in writing, as in declamatory acting, acrobatics, or tall-tale telling, could signal difficulty to readers and thus enable them to recognize an achievement. And it could signal energy too.

Dickens, of course, overtopped all writers in the period to an amazing extent. Every critical review-and there were many of them, for his success inevitably engendered the desire to find something wrong with his work-concluded by acknowledging that even his failures were better than the best most novelists 
could achieve, and that in each of his works there was matter for a dozen ordinary novels. If there was any democratic hope that a great writer could be greatly popular, Dickens encouraged it; if there was any inclination among writers and critics to believe that the public could not appreciate literary greatness, Dickens undermined it. Dickens's secret-and it was a secret in that nobody knew how he did it-was in his fertility, his energy, his apparently inexhaustible creativity: in a word, the life in his fictions. Certainly one aspect of this life was to be found in his matchless, though far from faultless, style.

"His command over the English language in its most native and idiomatic parts is really marvellous. . . . His style is original, almost beyond that of any writer of English in this age ... formed from the commonest materials, selected with an instinctive tact and used with singular directness and force. It abounds in racy and expressive idioms, and has a strange flexibility in conveying at once to the reader's mind every variety of thought and passion. It may be said to be unstudied, though it must have required long habits of composition to bring it to its present state of completeness" (North American, January I 843). "Why is it," Godey's asked, "that Charles Dickens is so universally and unabatedly delightful?" A "principal cause" was "the unfailing spring of original turns of wit, turns of phrase, and turns of thought that give the rare delight of novelty, and the pleasure of something unexpected" (June i 85 I). "Such are the attractive and winning graces of his style," Putnam's said, reviewing Bleak House, "that he can, when character and incident fail him, always secure the reader's attention by mere profuseness of riotous rhetoric, which has no other use than that of diverting his reader" (November I 853). In contrast, the American Review, writing on the same novel, objected to his "use of nominatives without verbs, verbs without nominatives, and pronouns without substantives," querying, "will those writers who are faithfully cultivating purity of style and exactness of finish, become depressed by the superior success of a more careless literature? . . . Will the faults of this wonderful author share the same apotheosis as his virtues?" Of course, the journal admitted, it is "beyond Mr. Dickens' power to make a failure. If he should write a book in ten days . . . it would still be a book worth buying and reading" (September I 852).

The example of these three writers shows that to be individual 
in style meant, as by definition, that one could not be exemplary; the original stylist necessarily broke rules, was incorrect, improper, verged on the ludicrous, offended a correct taste. The equation of grammatical and moral propriety is not accidental; an apostle of "grammatical free love" opens the door to freedoms in other areas as well. The use of the words pure and chaste to describe a proper style is thus significant. To break rules is to indulge; to indulge successfully is to put rules themselves in question. Whether the novel might be used as an instrument of making people better or not, even to the extent of making them more sensitive to good literature, depended to some degree on whether it might help people appreciate rules. "Slang," the New York Ledger editorialized, "is disgusting to every noble and considerate mind. In speech, God has given us our highest gift and grace; and when language is made the pure vehicle of pure and good thoughts, must glorify himself and his kind. It is lamentable and shocking, the extent to which slang phrases have corrupted the current speech of our time. Senseless and idle words have crept in and crowded out their infinitely betters, until there is scarcely a vestige of society that does not daily degrade our sterling mother tongue. . . Thrice enemies of true civilization are they who cultivate slang" (June I 2, I 858).

There was one popular subgenre of the novel that allowed slang and depended, in contrast to the "novel proper," on a certain stylistic laxness. "The mere announcement of any thing from the sparkling brain of the Bachelor of the Albany," Grabam's wrote of one of these, My Uncle the Curate, "is sufficient to raise anticipations of brisk and business-like satire, of felicitous expression, and of good-natured representation of the follies of conventional life. The present work evinces more of the novelist, and less of the wit-snapper, than any thing the author has previously written. The story and the characters, though plentifully bespangled with epigrams, are still not immersed and lost in them" (July I 849). The chief example of this subgenre, survivor of the picaresque, was Charles O'Malley ( 1840 ), by the Irish author Charles Lever. The type consisted of a string of episodes connected through the hero; the episodes might be exciting but were more usually humorous, and the work as a whole functioned mainly as the occasion for witticisms and jokes. Many examples of the type were reviewed in American journals of the 1840 and 
early I 850 , always in the same way: "we have not, for a long time, found a novel so full of real good and pure fun. . . . There is not a dull page in the book. Incident upon incident, joke upon joke" (Godey's on The Marrying Man, September I 84I). "Quaint and delightful ... rich and racy, serious and comical, still-life and adventurous, rollicking and frollicking" (Godey's, October I 847). "If any of our readers are afflicted with the blues, or likely to become so, we recommend to them as a most effectual remedy or preventative, to go and purchase" The Image of His Father (Southern Literary Messenger, November I 848). Neither Valentine Vox nor Frank Farleigh, according to Peterson's, could be read "without incessant fits of laughter" (September I 850).

Given that the success of these works depended on some degree of linguistic license, it is noteworthy that they were strongly male-centered in story line and involved a good deal of masculine misbehavior. Style and content seemed to coincide: "the interest depends more upon the immediate and unconnected adventures of the hero, than upon the intricacies or ingenuity of the plot. We are no admirers of this facile and rambling style of novel-writing," the Mirror commented on an American example, Harry Franco (by Charles F. Briggs) on July 6, I 839. "There are, however, many good hits. . . . The slang phrases, which he puts into the mouths of some of his characters, are but too faithful transcripts of the Americanisms, in which many of our young men rejoice. We cannot commend Harry Franco very warmly to the favorable regards of our fair readers." Oddly, the women-centered journals-Godey's, Peterson's, and Grabam's-were more favorably disposed toward these funny books than the other magazines even though it was taken for granted that only men would write them. Insofar, then, as linguistic boldness involves, for American authors, the utilization of slang, or "Americanisms," we do have the beginnings of a sexual demarcation of style in novels, but one that seemed to be working in favor of women writers rather than against them, in that slang or colloquial writing could be neither elegant nor pure. The allowable license of these comic books did not seem to promise literary stature or achievement, and certainly it did not point at that time toward the serious novel or the dedicated artist.

If a purely comic book was a minor subgenre of the novel, humor was nevertheless an anticipated element of all novels. 
Reviewers looked for passages of humor, for passages of pathos, and above all for the combination in a novel of both humor and pathos. The term pathos was used by reviewers to denote an emotional response (or its provoking cause in the text) characterized by pity, sadness, or sorrow-"to dissolve the heart in tears" (North American, July I 822 ). The provocation would usually consist of instances of sadness or suffering in the novel's events, creating a sympathetic mood in the reader, but successfully created pathos depended as much on authorial handling as on situation. All good novels were expected to contain pathos. Better novels also contained humor, with the result that a reader moving forward on the track of an exciting story would also oscillate emotionally across that track through experiences of contrasting pathos and humor invested in smaller plot segments.

We see this notion articulated in an early review in the North American (of Sedgwick's Redwood, April I 825): "parts are written with deep pathos; others display no inconsiderable share of comic power." "If any jaded romance-reader would have an honest natural laugh and cry . . . let him ... pass to-day with Uncle Philip or the Barclays," it wrote about some other Sedgwick stories in October I 837. It faulted Cooper in July i 850 for an "almost total want of humor and pathos" and praised Mary Jane Holmes's The English Orphans in October I 855 because the "pathetic element ... . is highly wrought, yet stops short of mawkishness" while "the comic vein is worked with equal success, and with equal moderation." These examples show a persisting criterion through more than a quarter-century of reviewing in this journal.

And we see it in other journals too. "Sadness and humor,tears and broad grins, - are sprinkled . . . throughout the whole volume" (Knickerbocker, January I 835). "It made us laugh, it made us cry" (New York Review on Sedgwick's Live and Let Live, October I 837). "Touches of the most exquisite pathos," Godey's reported (July I 840), and noted again that a novel had "pathos and beauty" that "cannot fail to charm the reader" (January I 859 ). The Democratic Review found "innumerable touches of pathos" in McIntosh's Two Lives (December I 846) and described Cornelius Mathews's Moneypenny as “abounding in scenes of great pathos, contrasted with passages of broad humor and laughable caricature" (September I 850). "The humor and pathos are effectively 
blended" in Dombey and Son (Literary World, July 17, I 847); a reviewer in the same journal complained that "the pathos and humor" of Uncle Tom's Cabin had been "very much overstated" (December 4, I852).

Grabam's, though praising The Scarlet Letter (May i 850), added that "in his next work we hope to have a romance equal . . . in pathos and power, but more relieved by touches of that beautiful and peculiar humor . . . in which he excels almost all living writers." Harper's, from its first issue on, praised "touches of humor and pathos" (June i 850). "For pathos, we know not her equal" (Home Journal, March 22, I 85 I); "a story of uncommon power and pathos" (Arthur's Home Magazine, July I 853 ); "gentle pathos," "quiet humor and pathos," "frequent touches of pathos" (Tribune, July I2, I854; May I 5, I855; June 23, I857). "Alternate pathos and humor" (Putnam's on Stowe, January I 855 ); "the narrative is full of humor and pathos" (Atlantic on Eliot's Scenes of Clerical Life, May I 858); "there is a good deal of humor in the work; in fact the author succeeds in this line better than in pathos" (Peterson's on The Quaker Soldier, March I 858); "the work is excellent, in all respects, but it is in pathos that the writer excels" (Peterson's on Vernon Grove, December i 858); and so on.

The stability of this criterion and the frequency of its recurrence in reviews throughout the period testify to the profoundly emotive view of the novel-reading experience. Without spending much time on the issue of how it might be that people enjoyed being made to feel bad, reviewers combined a simple Aristotelian notion of catharsis with a Shaftesburian sense that deep emotion called up on another's behalf was morally uplifting. Humor, with its power to startle, clarified and added the pleasure of surprise. The combination provided an emotional variety in the reading experience that both enhanced and relieved the progress of the story toward its denouement. The point to be stressed is that the chief principle of elaboration within the novel is emotional rather than thematic, and it is the job of the author to handle scenes so as to produce these various emotional responses. As with considerations of style, it is the drift of this criticism to impose a certain uniformity on authors rather than to encourage them in individuality.

The all-important requirement for formal closure, an apt denouement, in the novel, is paralleled by an expectation that there 
will be emotional closure as well. The plot arouses and relieves a set of emotions including suspense, curiosity, interest, and sympathy; all of these will be satisfied by the outcome of a good novel in a way that finishes the experience but does not end the desire to read more novels. Pathos and humor also call for emotional completeness, the name for which was, simply, tone. This word was deployed more narrowly than it is now, since New Criticism and authors of composition manuals have elaborated it to imply all aspects of authorial attitude. It referred to the author's implicit attitude toward the events and characters in the book viewed as though they were real occurrences and existences, and there were only two tones: healthy and morbid. If the author liked his characters, the tone was healthy; if not, not.

"The highest charm of the book is its pure and healthy tone of feeling" (North American on Bremer's The Neighbors, April I 843). "It gives cheerful and animating views of human life and the Providence that governs it. . . The author's mind is an eminently healthy one. . . . She has looked at the world through no false and distorting medium of pride or gloom." "The tone of the book is healthy" (Peterson's, July I 852 on Warner's Queechy); the Christian Examiner complained that Alice Carey's Hagar was "nowhere relieved from an unhealthy, painful burden of morbid tone" (September I 852); "the author's tone of thought and sentiment is sound and healthful" (Arthur's, June I 855); "its tone is unhealthy" (Atlantic, December I 859). In October I 852 Grabam's wrote about Melville's Pierre that "none of Melville's novels equals the present in force and subtlety of thinking and unity of purpose. . . . A capacity is evinced of holding with a firm grasp, and describing with a masterly distinctness, some of the most evanescent phenomena of morbid emotions. But the spirit pervading the whole book is intolerably unhealthy." Morbidity means disease, an unnatural condition. Health is natural, undistorting.

An excellent discussion of a related general principle of importance here occurs in a Grabam's review of Hawthorne's The Blithedale Romance (September 1852). "The ordinary demand of the mind in a work of art, serious as well as humorous, is for geniality - a demand which admits of the widest variety of kinds which can be included within a healthy and pleasurable directing sentiment." In Hawthorne, the journal went on, "geniality can- 
not be said to predominate. Geniality of general effect comes, in a great degree, from tenderness to persons; it implies a conception of individual character so intense and vivid, that the beings of the author's brain become the objects of his love." The healthy tone, then, implies first that the narrator-author's attention is directed away from himself and toward the beings he has created, and second that his attention to these beings is loving. Conversely, the unhealthy tone may come about either because the author's attention, directed toward himself, fails to encompass (and hence to realize) his characters, or because though directed at those characters it is not loving.

The Grabam's reviewer suggests that characters realized with sufficient intensity must of necessity become the objects of their creator's love; self-obsession and misanthopy alike might hinder an author from the investment in his characters that brings love inevitably in its train. The formulation shows us how the most self-effacing author can also be deeply and evidently present in a work, in that the characters are now seen to be constructed, in an important way, of the author's attitude toward them. Here, in effect, reviewers acknowledge that characters in fiction, created by language, are essentially unlike characters in real life, in that the mark of authorial love is (or is not) clearly inscribed in them. A secular, real-life fear-of being unparented, or at least unloved - is admitted and rectified in the genial work, admitted and sadistically enhanced in the morbid one.

It is an easy slide from this position to the assertion that human nature is validated or vindicated in the work with a healthy tone. The Mirror observed that a "great charm and merit" in G. P. R. James's novels was "the healthy moral tone which pervades them. They have none of that morbid misanthropy, that frantic feebleness, which is too often affected by the authorlings of the day" (February 9, I 839). And Knickerbocker praised the "highly moral and healthful tone" of Kate Aylesford, which "comes like a refreshing breeze from the bosom of old ocean, to clear away the hot, sickly and foggy sentimentalities of the day. The characters are real flesh-and-blood individualities. Every one is drawn so true to life, that no doubt of the writer's fidelity to nature startles the reader's credulity; no suspicion that poor, weak humanity is slandered, arises to disturb the interest of the story" (May i 855 ). The reviewers' language shows, too, that tone, though rising from the 
whole book ("the spirit pervading the book," the "directing sentiment"), is directly referable to the author. "The general tone of the author" of Vanity Fair, according to Grabam's, "is distinguished by singular manliness, cheerfulness, and generosity"; Charles Reade's "novels are not only good, but have something peculiar in their goodness, derived from his own character. . . . One rises from reading his books, not merely with the sense of delight at his brilliancy, but healthier in mind and feeling. . . . Beneath all his rapid, brilliant, and varying narrative, his felicitous, though somewhat sketchy characterization; his effective situations, and even his brisk, sparkling epigrams, there is a remarkable freshness, geniality, and simplicity of nature" (November I 848 , August I 855 ).

The healthy, the genial, tone is a matter of author love and makes the experience of novel reading life confirming and enhancing. "The mere power and variety of his imagination cannot account for his influence," the Atlantic wrote on Walter Scott (May I 858), noting the publication of a household edition of his works, "for the same power and variety might have been directed by a discontented and misanthropic spirit, or have obeyed the impulses of selfish and sensual passions, and thus conveyed a bitter or impure view of human nature and human life. It is, then, the man in the imagination, the cheerful, healthy, vigorous, sympathetic, good-natured and broad-natured Walter Scott himself, who, modestly hidden, as he seems to be, behind the characters and scenes he represents, really streams through them the peculiar quality of life which makes their abiding charm." In a similar spirit, the Democratic Review had written in September I 853 that "one thing peculiarly distinguishes [Scott's] writings. It is the spirit of broad philanthropy which breathes through them-the spirit which can only emanate from a kindly and generous heart."

The issues here are both substantive and formal. The lovability of human nature itself is at stake. It would not matter so much that a writer not convey a "bitter or impure view of human nature and human life" if the reviewers did not think such a view might have some truth to it, and fear that truth. Formally, since the dynamics of all plots depended on sympathy and interest, a novel without sympathetic or interesting characters could not but be a formal and experiential failure. And, too, an author who presents unlova- 
ble characters, or who presents lovable characters without loving them, probably does not love his readers either, and it is difficult to see how engagement with such an author could be the occasion of a pleasurable experience, or why readers should choose to read novels that subject them to an author's contempt or dislike. In essence, the wrong authorial tone pointed to a sort of egotism on the writer's part, where he asserted that he was more interesting than the story he had to tell. The morbid author loves himself.

Here is the repeated point at which a formal judgment of narrator efficacy and an ethical judgment of authorial character intertwine. "The habit of intense brooding over individual consciousness, of making the individual mind the centre and circumference of everything, which is common to many eminent poets of the present age, has turned most of them into egotists, and limited the reach of their minds," the North American explained in a review of G. P. R. James (April I 844). "The greatest novelist should be a poet, philosopher, and man of the world, fused into one," it continued in a review of Dombey and Son (October I 849). "It is evident that this exacting ideal of a novelist has never been realized. In most of the novels written by men of powerful talents, we have but eloquent expressions of one-sided views of life. In some, the author represents himself, ideals of himself, and negations of himself, instead of mankind." "Each author has drawn what he saw, or knew, or did, or imagined; and so has preserved something worthy, for those who live upon his plane and see the world with his eyes. The difficulty is, that the vision of most men is limited; they observe human nature only in a few of its many aspects; they cannot so far lift themselves above the trivial affairs around them as to take in the whole of humanity in a glance" (Atlantic, September I 859).

Given the inevitable limitations of the human grasp, the narrator, though apprised of all the secrets of his story and presumably skilled in knowledge of human nature, was not expected to assume the stance of a deity in the story. But neither was he or she expected to take up the novel's space with self-display and selfcharacterization. What was looked for was an exemplary stance, a representation of the large-spirited, generous, magnanimous human being who is thought of as an ethically admirable character. The author in the novel, then, is a type rather than an individual, and strategies that individualized the narrator were 
perceived as both morally and technically defective. We realize, all the more since this time period represents a crucial stage in the development of the idea of the individual, and since indeed individualizing was the chief criterion by which characterization in the novel was judged, that the narrator spoken of here must be a wholly fictive representation devised for the sole purpose of effective storytelling. Each narrator is judged against a fixed ideal of narrator presence. There is no thought that different stories might call for different kinds or representations of narrators. But paradoxically, the narrator is assumed to be the model of a real human being, faithful as far as it goes to the state of mind of the real author writing the novel. Certain states of mind not only are judged to be more efficacious for the purposes of good storytelling but also are assessed in and of themselves, for their moral worth. The distinction between better and worse novels becomes, or begins to become, a distinction between the quality of the moral vision as exemplified in the representation of the author through the narrator. The drift away from story, which we perceive emerging whenever reviewers try to sort out novels by quality, can be seen clearly here.

Judging the moral vision of the narrator, reviewers assumed they were talking about the real author. Were there any instances in which the equivalence of narrator with author was not taken for granted? Criticism of the time recognized only one deviation from a novel narrated by its author, a form they called the "autobiography," and by which they meant what we now call firstperson narration. References to this form abound in the 18500 , though they are very rare earlier, a fact that suggests a change within the novel itself. In all probability the development can be traced to Jane Eyre. The Cbristian Examiner blamed that novel for the immense popularity of the autobiographical mode: "the introspective autobiography has been overdone. No person of original genius or force of mind can indulge further in this style of thing, unless a new path is opened, or new depths revealed, unexpected heretofore" (March I 859). The Tenant of Wildfell Hall was an autobiography (Literary World, August I 2, I 848); so were Florence Sackville, Villette, Jane Eyre, and The Heiress of Greenburst (Harper's, February 1852, April I853, July I 857), Berenice (Home Journal, May 3 I, I 856), While It Was Morning (Ladies' Repository, January i859), and many more. 
The autobiographical form was associated largely, though not exclusively, with women writers and even more with novels featuring a female as the leading character. But Peterson's and Grabam's both used the term for Thackeray's Henry Esmond, the latter journal commenting in February I 853 that the novel was "in autobiographical form, and all the incidents and characters are viewed through the medium of an imagined mind-one character giving the tone to the whole representation." A Knickerbocker review for January I 854 praised Wilkie Collins's The Bloodstone for combining "the charm of an autobiography with the high-wrought interest of a tale."

The formal difference between the autobiography and the dominant mode was, simply speaking, that the former was narrated by a character while the latter was narrated by a representation of the author. What were the attractions and limitations of the autobiography in comparison to the normal mode? Given our interpretive interest in fiction, we tend to approach a question like this in an epistemological mood, thinking about how we are granted access to and knowledge of events in the novel. For these earlier reviewers such considerations did not figure. References above to tone and charm indicate a different center-as usual, that of interest. By making the main character narrate his or her own story, the novelist invested a more exclusive interest in that character and allowed the character a more intense presence than where the character was distanced from the reader by the intervention of a noncharacter narrator. "The interest of the story," a Harper's reviewer wrote in April I 857 about The Days of My Life, is "chiefly concentrated on the heroine, whose frank and artless relation of her history secures a sympathy with her fortunes, and compels the reader to listen to her naive recital as to an account of private experience." Similarly, a review in Peterson's observed that "the autobiographical form" in The Heiress of Greenhurst "affords a better play to the delineation of high passion than any other style" (August I 857). Closing the gap between reader and character, the autobiographical mode permits, indeed "compels," a closer involvement and a more intense reading experience.

On the other hand, the autobiographical mode imposes a new distance between the reader and story events, since one is restricted to the knowledge of the narrating character. The increasing separation of character from plot, and the increasing interest 
in the inner life as the locus of action, both find expression in the growth of the autobiographical mode, which confines attention to one character. "The autobiographical style of narration," observed the Literary World, "except in very skillful hands, fetters plot and restrains freedom of description" (March 9, I850). A sacrifice of breadth for intensity was thus the bargain struck by the autobiographical novel, and only a handful were noting its potential to change the terms of novel reading.

One author who induced such perception was Hawthorne, as a Grabam's reviewer reported of The Blithedale Romance in September I 852 . The "interest" of that work centers in the characters of Hollingsworth, Zenobia, and Priscilla, who are "represented as they appear through the medium of an imagined mind, that of Miles Coverdale, the narrator of the story." He "only tells us his own discoveries; and there is a wonderful originality and power displayed in thus representing the characters. What is lost by this mode, in definite views, is more than made up in the stimulus given both to our acuteness and curiosity, and its manifold suggestiveness. We are just watchers with Miles himself, and sometimes find ourselves disagreeing with him in his interpretation of an act or expression of the persons he is observing." Blithedale is unique in its use of a subsidiary character as narrator rather than the main character; because of this it really does not fit the acknowledged category of autobiography, and it thus emerges as one of the most "advanced" works of the era. Unlike the other autobiographies reviewed, it was concerned with limitations-on knowledge and interpretation of events-rather than with enhancement of affect.

There is no mention in these discussions of the narrator of the device of the limited third-person narration. If the novel was not recited by one of its characters, then it was recited by the novelist, who, as we have seen, was fettered only by the limits of his own character and certainly not by lack of knowledge about the story or its agents. The only serious criticism of narrator deployment, besides the frequent complaints about authorial tone, involved intrusions-or more properly speaking extrusionswhich were identified as one of the chief defects of the old-style novel. As early as July I 825 the North American credited Scott with overturning the convention of the authorial intrusion: "the writer's aim is to keep himself out of sight, or to appear only like 
the ancient chorus, to connect the parts of his story." From our vantage point Scott seems a highly intrusive author; since reflections and other forms of authorial commentary were well accepted, we realize that the criticism applied to a limited category of rhetorical strategies, specifically those in which the author reminded readers of his presence as author, consequently pointing out that the work was only a novel, as in this March I 845 comment on Fielding in the Democratic Review: "the frequent communings of the author with his readers produce a disagreeable effect. They do away the illusion by bringing too often the writer, instead of the actor, before the reader." "There is one thing in the work which we consider a fault, though we regret to say it is a very common one. . . We mean that of speaking in the person of the author.... The manager who pulls the wires should never be seen by the spectators" (Mirror, July 7, I 838).

The American Review voiced the same objection about Longfellow's Kavanagh: "we voluntarily give ourselves to the perusal of a fiction, and losing that consciousness as we proceed, should never be permitted for a moment to recall it; for the time the imaginary must stand for the real, and no inconsiderate assertion of the author should dispell the illusion" (July I 849). "The novelist should never do anything to cause a recognition of his personal existence" (Tribune, November I 3, I 850). "He is the invisible agent that moves the magic machinery by which you are transported into a region of illusory enchantments. . . . The moment you perceive the finger of a man the fond deception vanishes." "The illusion of the story is sometimes impaired by the introduction of the novelist in the first person, a blemish which we should hardly have looked for in a writer who is so obviously well acquainted with the resources of artistic composition as the author of this volume" (Harper's on Mayo's The Berber, October I 850 ).

The narrowness of the category of authorial intrusion, compared with our post-Jamesian distinctions, points to a different sense of the way the novelistic illusion is maintained from that operative in contemporary criticism. The difference lies again in our epistemological, as opposed to their affective, approach to the novel. Modernism, believing the authorial presumption of omniscience to be hypocritical, decries the very stance of the narrator as illusory. But this objection posits a narrator commenting 
about real people, knowledgeable about the real world rather than presiding over an artifical region; in a curious sense it is more naive than the view that assumes from the first that one is dealing with a story referring to real life rather than with real life directly and accepts the narrator or author as the chronicler of a story. From this view the narrator has a set of appropriate activities to carry out, and his assumption of knowledge about the story he is telling is nothing but the simple reflection of a fact. The only inappropriate activity is that of stopping his narration to remind auditors (or readers) that he is narrating, that his story is no more than a story. While all in the audience know perfectly well that the novel is no more than a story, the rhetorical act of reminding them of this breaches convention, since everybody is engaged in a transaction that involves pretending the events narrated are real. To point out the pretense changes the status of the characters from pretended real beings to real fakes; and it also undermines the reader's trust that the game's rules are being observed.

Simply, authorial intrusions make a reader seem foolish. The only reason for revealing himself as author, from the author's point of view, would be to gloat in his power over the reader; as he does that, the author loses that power, since the reader's participation is entirely voluntary. Once again we are in the presence of the self-displaying author, as opposed to one who directs his energies toward the characters he has created, the story he is telling, and the readers who receive it. The tendency of mind that might erupt in an authorial intrusion was precisely the one that would be morbid in tone, and for the same reason: putting oneself ahead of obligations. Egotism. "The characters, if they can be so called, in a fiction like Ernest Maltravers, are all shallow. Most energetic and various are they in deed, and copious in speech, but they act and speak at the command of that most potent and arbitrary of powers, the will of their literary father; they are not endowed with independent life. The character, therefore, into which in the course of a volume we get the most insight, is that of the author" (New York Review, January I 838 ).

"He is the best novelist who describes men with perfect fidelity, and yet leaves upon the mind the impression which the best men have in contemplating life," Harper's explained in Au- 
gust I859. There is inevitably an author in the novel and the more exemplary a human being he or she appears to be, the better the novel. Crude authorial self-absorption impeded narration and was a formal defect wherever it appeared; but the demand that a novelist represent objective reality, or life as it is, goes much further. Criticism of the novel becomes a criticism of the author's human grasp rather than of artistic skill. 